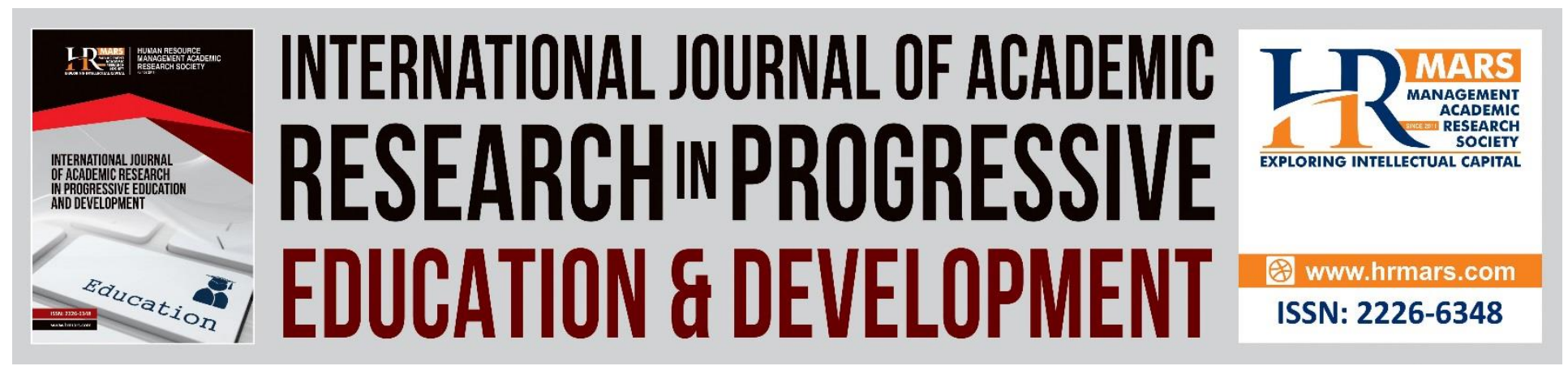

\title{
The Inculcation of Higher Order Thinking Skills in History Subject through the Application of Multiple Intelligence Theory
}

Sivapakkiam a/p Ramasamy, Fadzilah Abd. Rahman, Umi Kalthom Abdul Manaf, \& Rozita Radhiah Said

To Link this Article: http://dx.doi.org/10.6007/IJARPED/v7-i4/4801

DOI: $10.6007 /$ IJARPED/v7-i4/4801

Received: 29 Sept 2018, Revised: 22 October 2018, Accepted: 02 Nov 2018

Published Online: 10 Nov 2018

In-Text Citation: (Ramasamy, Rahman, Manaf, \& Said, 2018)

To Cite this Article: Ramasamy, S. a/p, Rahman, F. A., Manaf, U. K. A., \& Said, R. R. (2018). The Inculcation of Higher Order Thinking Skills in History Subject through the Application of Multiple Intelligence Theory. International Journal of Academic Research in Progressive Education and Development, 7(4), 51-59.

Copyright: (C) 2018 The Author(s)

Published by Human Resource Management Academic Research Society (www.hrmars.com)

This article is published under the Creative Commons Attribution (CC BY 4.0) license. Anyone may reproduce, distribute, translate and create derivative works of this article (for both commercial and non-commercial purposes), subject to full attribution to the original publication and authors. The full terms of this license may be seen

at: $\underline{\text { http://creativecommons.org/licences/by/4.0/legalcode }}$

\section{Vol. 7, No. 4, 2018, Pg. 51 - 59}

http://hrmars.com/index.php/pages/detail/IJARPED

JOURNAL HOMEPAGE

Full Terms \& Conditions of access and use can be found at http://hrmars.com/index.php/pages/detail/publication-ethics 


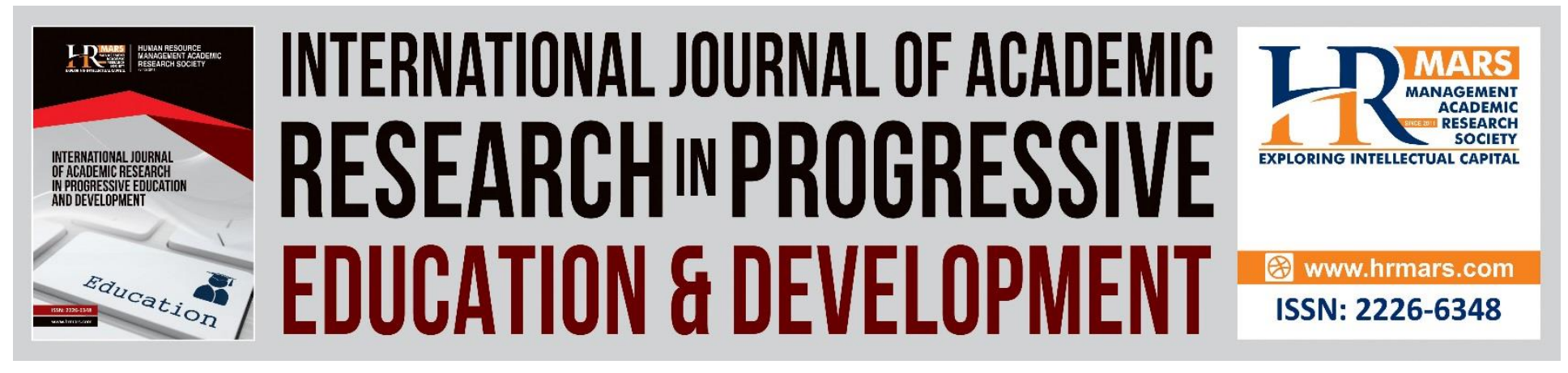

\title{
The Inculcation of Higher Order Thinking Skills in History Subject through the Application of Multiple Intelligence Theory
}

\author{
Sivapakkiam a/p Ramasamy, Fadzilah Abd. Rahman, Umi \\ Kalthom Abdul Manaf, \& Rozita Radhiah Said
}

Faculty of Educational Studies, University Putra Malaysia, 43400 UPM Serdang, Selangor Darul Ehsan, Malaysia

\begin{abstract}
In accordance to the needs and current educational policy, higher-order thinking skills (HOTS) have become the focus in daily teaching and learning processes. History is regarded as a mustpass subject for the Malaysia Certificate of Education (SPM) since the year 2013. Therefore, the Ministry of Education of Malaysia (MoE) highly recommends History teachers to apply various teaching strategies that could attract students' interest towards learning the subject. One of which is the Multiple Intelligence Theory, proposed by Howard Gardner in 1983. A qualitative study was carried out to identify the types of multiple intelligence applied and the teaching approaches that complement the identified intelligence during the inculcation of HOTS in History subject. The samples involved were three Excellent History Teachers. The data were collected through the process of triangulation, of which teaching and learning process observation, interview, and document analysis. The data were then analysed and triangulated using the ATLAS.ti 7.0 software. The findings showed that all informants applied the verbal-linguistic, interpersonal, and visual-spatial intelligence dominantly during the process of inculcating HOTS in History subject. Excellent History Teachers were also found complementing other teaching approaches such as discussion, questioning, and graphical presentation with the appropriate multiple intelligence in inculcating HOTS among students.
\end{abstract}

Keywords: Multiple Intelligence, Higher-Order Thinking Skills, Excellent History Teachers, Teaching Approaches

\section{INTRODUCTION}

The national educational system is currently aiming towards developing a productive and innovative society. As a nation that is rapidly developing in various aspects of development, in parallel, educational sector is expected to evolve and uphold a new set of paradigms, of which in return will promote innovations in all aspects of education. Improvements and the introduction 
INTERNATIONAL JOURNAL OF ACADEMIC RESEARCH IN PROGRESSIVE EDUCATION AND DEVELOPMENT

Vol. 7, No. 4, 2018, E-ISSN: 2226-6348 @ 2018 HRMARS

of new educational policies within the educational system are a crucial step in elevating the dignity and status of Malaysia in the eyes of the world.

\section{Background of Study}

The inculcation of thinking skills is not new within the national educational system. The Critical and Creative Thinking Skills (KBKK) have been implemented since the 1990s. Within the Malaysia Education Blueprint (PPPM) 2013-2025, the inculcation of HOTS element is seriously emphasised. The MoE has defined HOTS as the ability of a student to apply the knowledge, skills, and values that he or she has acquired during the process of postulating and reflecting problems, decisionmaking, innovation, and creativity (Lembaga Peperiksaan, 2013).

HOTS involve high intellectual skills. According to PPPM, every student must acquire various cognitive skills, including postulation and critical thinking, creative, as well as innovative. Since it is found that these skills are not being given the emphasis, in return, students are found lacking in applying the knowledge and think critically beyond the context of academic (Kementerian Pendidikan Malaysia, 2013). HOTS require an individual to think before explaining a phenomenon based on a thorough analysis, evaluation, idea generation, choices in decision-making, problemsolving technique, and proper planning. MoE gives a serious emphasis on HOTS inculcation among students to produce a generation of whom able to compete and being productive globally. Students with HOTS are given the freedom to compare, contrast, organise, classify, and identify cause and effect according to their opinion and views of their own.

HOTS in the context of History subject will enable students to give answers in many forms, creating new ideas, of which could help them to view History from various perspectives regarding an event and connect them with current issues. This kind of exercise is what is known as creative, innovative, and critical thinking skills among students. Therefore, to make sure the success of inculcation of HOTS among students, teachers need to act as significant medium or a catalyst. Indeed, such responsibilities must be carried out wholeheartedly. Teaching approach in History subject must be diversified by integrating several learning theories and proper techniques that are in accordance with the needs of today's educational settings (Ahmad, Seman, Awang \& Sulaiman, 2015).

Multiple Intelligence Theory is a learning theory purposed by Howard Gardner in 1983. Multiple Intelligence Theory is important due to its close relationship with the field of education. It is widely accepted that students do possess various intelligence and the way they think, act, and learn are indeed different from each other (Gardner, 1993). Theoretically, multiple intelligence is comprised of eight categories, of which each describing the tendency of an individual; verballinguistic, logical-mathematical, visual-spatial, bodily-kinaesthetic, musical, intrapersonal, interpersonal, and naturalistic (Gardner, 1983). Spiritual intelligence is recently added by Gardner in 1999. Various studies were carried out to prove that an education based on multiple intelligence is indeed capable of developing students' talents and potential more as compared to an education that is not. 


\section{Problem Statement}

An interesting teaching approach will enable students to actively engage in teaching and learning activity of History subject. However, most of History teachers are found still applying outdated teaching approaches during their daily teaching and learning activities. Since current teaching practices are focusing more on excellence in examinations and ' $A$ ' count, History teachers are often observed practising the memorisation technique during their teaching and learning sessions. History teachers are also found lacking in implementing innovative teaching approaches, of which if implemented will enable them to improve and diversify their teaching skills during the process of producing excellent students in History subject (Jabar, 2010).

Perhaps one of the reasons such predicament occured is due to fact that teachers' knowledge on implementing HOTS is still at infancy stage and therefore they are unable to emphasise HOTS as the main elements during their teaching and learning activities (Ramasamy, Fadzilah, Umi Kalthom, Habsah, Rozita, 2016). Khairul (2014) states that the main problem with Malaysia's thinking skills inculcation is that teachers are not given the required knowledge (declarative) and teaching skills (procedural). Since teachers are still lacking in HOTS, they are unable to inculcate HOTS during their teaching and learning sessions.

Most students can answer simple and short questions since it only requires them to memorise facts as compared to problem-based and opinion-based questions (Hamimi, 2013). In doing so, students are only applying the Low-order Thinking Skills (LOTS) rather than HOTS. Students are also found unable to relate past events with current issues. This is due to the lack of HOTS exposure among students.

\section{Research Objectives}

This study was meant to identify types of multiple intelligence applied by the History teachers to stimulate HOTS and to elaborate the teaching approaches that were simultaneously implemented with multiple intelligence to stimulate HOTS among students.

\section{Research Questions}

Based on the research objectives, two research questions were derived, of which firstly, what were the types of multiple intelligence applied by History teachers during their teaching and learning sessions to stimulate HOTS among students? And secondly, what were the teaching approaches used simultaneously with multiple intelligence to stimulate HOTS among students?

\section{RESEARCH METHODOLOGY}

A qualitative case study was implemented as the design of this study. The case was the usage of Multiple Intelligence Theory during the inculcation of HOTS. This study was carried out in two schools in the Federal Territory of Kuala Lumpur and a school in the Federal Territory of Putrajaya. The locations were chosen due to several factors such as schools with Excellent History Teachers, and various categories of school; Daily Secondary School, Boarding School, and High Achieving School. This study involves three Excellent History Teachers (EHT1 - EHT3) from various service grades and teaching experiences. Samples were full-time teachers who are still in service. 


\section{RESEARCH FINDINGS}

The data collected were analysed using the ATLAS.ti 7.0 software. The transcriptions were preliminarily prepared and validations were made by the informants involved. Next, the process of code determination was carried out based on the research objectives. The overall analysis was made based on the stipulated research questions.

a) The first research question was, what were the types of multiple intelligence applied by History teachers during their teaching and learning sessions to stimulate HOTS among students?

\section{Verbal-linguistic Intelligence}

All informants were found applying the verbal-linguistic intelligence as the dominant intelligence in stimulating HOTS among students. Students were given the opportunity to debate, giving an opinion, criticising peer opinions, and providing solutions to problems. Students were also found able to think with words in delivering their argumentation verbally and in a written from.

\section{Interpersonal Intelligence}

This type of intelligence was applied during the group work assignment, of which observed during the informants' teaching and learning sessions. Students were observed interacting with each other within their designated groups during the discussion of answering HOTS questions. The interaction amongst them, in return, produces high-order answers. This kind of answers can only be materialised through collaboration among group members, acknowledging others' opinions, and accepting recommendations from all group members. The inculcation of teamwork skills is observed throughout the GSCs' teaching and learning sessions. Indirectly, students were observed portraying their interpersonal intelligence. Teachers were also observed effectively inculcating HOTS among student during the process of ideas sharing among group members. Through the application of this type of intelligence, teachers could implement the studentcentred learning teaching approach effectively.

\section{Visual-spatial Intelligence}

The application of visual-spatial intelligence was observed routinely among all the EHTs in stimulating HOTS among students, especially through the usage of visualisation. Students were observed able to tell and visualise history events through a graphical presentation. Teachers were found stimulating HOTS among students through their abilities in giving their ideas through graphical sketches. Whenever students can illustrate their facts and ideas in the form of graphical presentation, it gives the impression that students are understood clearly the learning outcomes of the day. Instances of HOTS-worthy graphical presentation analysed in this study are,

b) What were the teaching approaches used simultaneously with multiple intelligence to stimulate HOTS among students? 


\section{Discussion Approach}

Discussion approach was observed simultaneously implemented with multiple intelligence such as verbal-linguistic, interpersonal, and visual-spatial. EHTs were observed giving HOTS-worthy questions to students to be discussed in their groups. During the discussion sessions, interpersonal intelligence was applied, whereas, during the presentations, verbal-linguistic and visual-spatial intelligence were applied by the students.

\section{Questioning Approach}

The stimulation of HOTS in History subject was observed through questioning approach. Questions that are based on various levels of thinking order were prepared and ready to be discussed and debated in groups. Students were stimulated to answer questions in the form of verbal communication and writings, with the use of their verbal-linguistic intelligence.

\section{Graphical Approach}

Findings showed that graphical approach was simultaneously implemented with visual-spatial intelligence. EHT 1 was observed applying the graphical approach during her teaching and learning session to stimulate HOTS among students. Apart from EHT 1, EHT 2 was also observed practicing the same graphical approach during her teaching and learning session. Students were observed presenting their discussions through pictures and mind map. This approach was also seen able to stimulate students' thinking skills towards History lesson at the level of imagination. Whenever students are imagining things, indirectly, their HOTS are also stimulated.

\section{DISCUSSION}

This study provides input on the success of simultaneous implementation of Multiple Intelligence Theory and History teaching approaches towards stimulating HOTS among students. Verballinguistic and interpersonal intelligence are two most dominant intelligence that need to be applied during the History teaching and learning session. Both intelligences need to be supported with other types of intelligence such as visual-spatial, kinesthetic, and musical for a much more effective inculcation of HOTS. Findings of this study also showed that discussion, questioning, and graphical approaches were simultaneously implemented with verbal-linguistic, interpersonal, and visual-spatial intelligence. The teaching approaches and intelligence observed and discussed in this study were found having strong relationships among them during the process of HOTS inculcation among students.

\section{Research Implications}

This study gives several impacts towards the theory and practice of History subject's curriculum in Malaysia. The main impact is none other than achieving the main objective of MoE's-producing individuals with HOTS so that they will be able to compete globally.

\section{History teachers' Teaching Plans}

This study shows the importance of teacher's daily teaching lesson plan. The application of learning theory such as Multiple Intelligence Theory as well as the appropriate teaching approaches is found effective in stimulating students' involvements in teaching and learning 

DEVELOPMENT

Vol. 7, No. 4, 2018, E-ISSN: 2226-6348 ๑ 2018 HRMARS

activities. Findings of this study also suggest that teachers should be aware and sensitive towards students' multiple intelligence during their teaching and learning sessions. Therefore, teachers are urged to plan their teaching and learning sessions towards promoting students' multiple intelligence.

\section{Integration of Multiple Intelligence Theory during daily Teaching and learning Activities}

This study revealed that the integration of Multiple Intelligence Theory during teaching and learning activity of History teachers did manage to create interest of students towards learning History. Creative teachers are those who can apply multiple intelligence in relevant topics and those who are able to practice the appropriate teaching approaches that are suitable to be implemented simultaneously with multiple intelligence. This approach, in return, helps teachers to conduct their teaching and learning sessions in the most enjoyable state as compared to the conventional teaching approach, of which focuses on teacher-centred technique. Indirectly, teachers will be able to inculcate HOTS easily among students.

\section{History Subject Curriculum}

According to the PPPM 2013-2015, an effective implementation of HOTS requires curriculum of all subject matters to be carefully coordinated. HOTS should be treated as the main elements within the national curriculum and all subject matters are expected to embrace the elements fully. In this regard, findings of this study will give impact to the current curriculum review for History subject. The elements of HOTS should be given the emphasis during the development of curriculum to make sure the accumulation of HOTS is possible in Malaysian educational settings.

\section{Recommendations}

The MoE should make sure all pre-service teachers are given the exposure regarding the appropriate application of Multiple Intelligence Theory and HOTS during their teaching and learning sessions. Teachers should be given the appropriate in-service training from time to time regarding HOTS inculcation, supported by several learning theories. The practice of integrating the Multiple Intelligence Theory and relevant teaching approaches should be given the emphasis since preschool.

Excellent History Teachers should act as main references when it comes to knowledge sharing on the best practices to inculcate HOTS among students. It could be done through collaborative workshops in teaching and learning among schools in a certain area or with the State Education Departments. Through this kind of knowledge and skills sharing by these Excellent Teachers to ordinary teachers, History subject will finally be known for its interesting and mind tickling teaching and learning session among students.

\section{Recommendations for Future Research}

This study only involves Excellent History Teachers. The findings do not represent ordinary History teachers. Therefore, future studies should involve ordinary teachers to understand the difference of HOTS inculcation among Excellent History Teachers and ordinary History teachers. The number of samples needs to be increased to gain more information pertaining to the application of Multiple Intelligence Theory and how HOTS are inculcated. 
INTERNATIONAL JOURNAL OF ACADEMIC RESEARCH IN PROGRESSIVE EDUCATION AND DEVELOPMENT

Vol. 7, No. 4, 2018, E-ISSN: 2226-6348 @ 2018 HRMARS

This study only involves secondary school students. History is a relatively new subject at primary schools. Therefore, future studies should be carried out at primary schools particularly towards the effectiveness of HOTS implementation in History subject. The recommendations are intended to observe the extent of HOTS stimulation, supported by multiple intelligence at schools. It is recommended that in the future, these studies are carried out using the experimental research design to determine the effectiveness of Multiple Intelligence Theory's application.

\section{CONCLUSION}

Findings of this study illustrate the effectiveness of HOTS inculcation through Multiple Intelligence Theory, as well as an excellent teaching plan. Teachers of whom are regarded as main agents of change in implementing MoE policies need to be more creative and critical in planning and implementing their teaching and learning activities. It is undeniable that HOTS are regarded as a catalyst for our educational system, of which in return will elevate our nation's advancement in the economy as well as well-being. Findings of this study are also hoped to illustrate clearly to the relevant authorities of how important it is for History teachers to apply Multiple Intelligence Theory in their teaching and learning sessions and how important it is to change the scenario of learning History from traditional to creative and innovative ones. The aim of MoE in producing HOTS generation can only be fulfilled if all educational entities are ready and willing to change the current practices of education in this country.

\section{Corresponding Author}

Sivapakkiam a/p Ramasamy, Faculty of Educational Studies, University Putra Malaysia, 43400 UPM Serdang, Selangor Darul Ehsan, Malaysia. Email: sivawpkl@gmail.com

\section{References}

Ahmad, A. R., Seman, A. A., Awang, M. M., \& Sulaiman, F. (2015). Application of Multiple Intelligence Theory to Increase Student Motivation in Learning History, 7(1), 210-219. https://doi.org/10.5539

Anderson, L. W. \& Krathwohl, D. R. (2001). A Taxonomy for Learning, Teaching and Assessing: New York. Longman Publishing.

Breakstone. J, \& Smith, M. (2013). The TPS Journal - Assessing Historical Thinking Skills Using Library of Congress Primary Sources, 1-8.

Gardner, H. (1983). Frames of mind: The theory of multiple intelligences. New York, NY: Basic Books.

Gardner, H. (1993). Multiple intelligences: The theory in practice. New York, NY: Basic Books.

Gardner, H. (1999). Intelligences reframed: Multiple intelligences for the 21st century. New York, NY: Basic Books.

Hamimi, K. A. B. (2013). Kemahiran Pelestarian Pemikiran Dalam Pendidikan Sejarah. Seminar Pendidikan Sejarah Dan Geografi, 2013, 29-30.

Jabar, B. (2010). Pelaksanaan Kemahiran Pemikiran Sejarah dalam Pengajaran Guru-guru Sejarah: Satu Kajian Kes di Daerah Hilir Perak.

Kementerian Pendidikan Malaysia. (2013). Pelan Pembangunan Pendidikan Malaysia 2013-2025, 2025. doi: 10.1016/j.tate.2010.08.007 


\section{INTERNATIONAL JOURNAL OF ACADEMIC RESEARCH IN PROGRESSIVE EDUCATION AND}

\section{DEVELOPMENT}

Vol. 7, No. 4, 2018, E-ISSN: 2226-6348 ๑ 2018 HRMARS

Khairul. (2014). Tahap Kesediaan Guru Pelatih Institut Pendidikan Guru Dalam Latihan Mengajar. http://doi.org/10.1017/CBO9781107415324.004

Peperiksaan, L. (2013). 11 anjakan yang terkandung dalam Pelan Pembangunan Pendidikan 20132025, 1-25.

Rajendran, N. (2001). Pengajaran Kemahiran Berfikir Aras Tinggi: Kesediaan Guru Mengendalikan Proses Pengajaran Pembelajaran. Kertas Kerja Ini Telah Dibentangkan Rajendran, N. S. (2000). Kesusasteraan Sebagai Wahana Mengajar Kemahiran Berfikir Aras Tinggi.

Ramasamy. S, Fadzilah A.R., Umi Kalthom. A.M., Habsah, I., Rozita. R.S. (2016). Journal of Modern Education Review, Volume 6, Number 9, 612-621. NY: Academic Star. 